\title{
Stylists in the American Grain
}

Wallace Stevens, Stanley Cavell and Richard Rorty

\section{Aine Kelly}

\section{(2) OpenEdition}

\section{Journals}

Electronic version

URL: http://journals.openedition.org/ejpap/918

DOI: $10.4000 /$ ejpap. 918

ISSN: 2036-4091

Publisher

Associazione Pragma

\section{Electronic reference}

Aine Kelly, "Stylists in the American Grain », European Journal of Pragmatism and American Philosophy [Online], II-2 | 2010, Online since 21 December 2010, connection on 01 May 2019. URL : http://

journals.openedition.org/ejpap/918; DOI : 10.4000/ejpap.918

This text was automatically generated on 1 May 2019.

\section{(c) (1) $\odot$}

Author retains copyright and grants the European Journal of Pragmatism and American Philosophy right of first publication with the work simultaneously licensed under a Creative Commons Attribution-

NonCommercial-NoDerivatives 4.0 International License. 


\title{
Stylists in the American Grain
}

\author{
Wallace Stevens, Stanley Cavell and Richard Rorty
}

\section{Aine Kelly}

\begin{abstract}
If there is now a tradition of American literature, it starts from penury of circumstance and achieves, at enormous personal cost, a style never secure in the possession of itself, but always pursuing its best and most difficult self. ${ }^{1}$
\end{abstract}

1 According to Denis Donoghue, the characteristic American style emerges from conditions amounting to failure. Achieving vitality by a conscientious labour to transform failure into success, its creativity proceeds not from abundance but from destitution, "converting penury in substance to plenitude in the realized form" (Style: 109). Like Richard Poirier, Donoghue locates this failure in the peculiarly American experience of a radical separation of imagination and reality, a rift between consciousness and experience. ${ }^{2}$ Both critics find in the American imagination a "desperate metaphysic," a failure to find proper sustenance in the given world. American writing, Donoghue finally contends, "is characterized by the precarious achievement of style"; it emerges most habitually "in conditions nearly desperate and against all the odds" (Style: 125).

Donoghue, of course, speaks for American literature before American philosophy. His essay draws on Henry James, Henry Adams and Allen Tate before turning to Wallace Stevens' late poetry and prose. Is it possible, however, that this "style of failure" might speak to the thinkers and writers of a specifically American philosophical tradition? Donoghue's hypothesizing, in the same extract, is more than a feature of his eloquent writing style and still questions, even as late as 1976, whether there is a tradition of American literature to speak of in the first place. Those wishing to make a claim for "American philosophy," not to mention the infinitely more specific and contentious claims for a characteristically American philosophical style, have a much tougher task than Donoghue's seminal essay, and significantly less firmer footing.

3 This in mind, I propose an unlikely trio of American writers - the modernist poet, Wallace Stevens, the contemporary philosophers, Stanley Cavell and Richard Rorty - as touch- 
stones for this debate, re-describers of its central thesis, as Rorty might say. Stevens, Cavell and Rorty have always been noted for philosophical commitment as well as stylistic flair. Most obviously united by a shared ability to inspire philosophical interest and passion, the writings of Cavell and Rorty provide a welcome addition to a professionalized discourse (that of contemporary analytic philosophy) too often marked by aridity and over-specialisation, while Stevens' epistemological promptings have long been considered an inspiring addition to philosophical schools as diverse as Husserlian phenomenology and Jamesian pragmatism. Encouraging a hearing between American literature and philosophy, all three writers highlight the issue and importance of philosophy's writing, as they work to find a place for literature in the philosophical conversation.

4 It is an accepted fact of philosophical and literary scholarship that the writing style of Stanley Cavell is difficult. Challenging, complex, intricate, intractable, obstinate, testing and tough - and that's for the reader with more than a passing familiarity with the writings of Cavell's chosen philosophical forbears: Ralph Waldo Emerson and Henry David Thoreau, Friederich Nietzsche and Martin Heidegger, Ludwig Wittgenstein and John Langshaw Austin. There's a profound sense of struggle in Cavell's writing, of intellectual labours enacted directly and unflinchingly in his reader's presence. Consider the passage from In Quest of the Ordinary where Cavell discusses the Wordsworth poem, "Intimations of Immortality from Recollections of Early Childhood": "In this poem, about recovering from the loss of childhood by recovering something of, or in childhood (in particular, recovering its forms of recovery), we are to recover it, participate in it, by imitating it, as it imitated us (so imitating its endless readiness for imitation)."

5 The phrasing here is endlessly refracted and recursive, as Cavell urges the recording of minute distinctions and clarifications, the murmuring of repetitions and variations, the parenthetic asides within clauses within asides. Typifying a writing practice that has a frustrating tendency to turn back on itself, and to do so just at the moment when it might begin to satisfy or even to progress, Cavell's sentence style refuses not just argument but the very promise of logical progression, of intellectual resolution, of cadence.

6 The self-conscious difficulty of Cavell's style is a feature he recognises in his own philosophical forbears, and one he relates specifically to the writing of philosophy in America. Cavell pictures Emerson's language as continuously struggling with itself, "as if he is having to translate, in his American idiom, English into English." ${ }^{4}$ There is an obvious frustration here, an inherited disappointment with the potentialities of American expression. Adding further weight to this Emersonian burden, and a further condition to which Cavell holds his writing responsive, is his sense of philosophy as now existing in a modernist state. As early as 1967, in "A Matter of Meaning It," Cavell had argued that all modernist art works (his examples ranged from Pop Art to the theatre of Beckett to the music of John Cage) are characterized by "the possibility of fraudulence." ${ }^{5}$ And just as there is no standing discourse that explains or justifies what modern art is, there is no standing discourse that accounts for the practice of philosophy. The implicit suggestion is that philosophy must continuously place into question and affirm its own identity; because of its vulnerability to "false seriousness," it must work to manage continuity with itself. "The writing of philosophy," Cavell affirms, "is difficult in a new way" (MWM: xxiii). 
7 Even more than this, however, Cavell's writing is intimately tied to the moral outlook he wishes to defend, that of moral perfectionism. Moral perfectionism is founded on the idea that there is an unattained but attainable self that one ought to strive to reach, an idea Cavell traces from Emerson to Nietzsche to John Stuart Mill, and detects traces of in Rousseau and Kant. Ironically, what critics sometimes interpret as an aversiveness in Cavell's style is partly explained by this perfectionism, this idea that we must continually fight towards expressiveness, that we are morally responsible for making ourselves understood by each other. Writing, then, cannot merely signify the clear formulation of texts and ideas but must enact a deeply personal work of self-critique and selftransformation. It is a challenging, a stretching, of one's actual self.

The burdens of self-expression weigh heavily on Cavell. His writing places extraordinary pressure on itself to describe, undistractedly and specifically, the processes of mind and the allusiveness of thought. This labour testifies not only to Cavell's modernism, to his perfectionism, but to his life-long wish to involve his writing in the procedures of ordinary language philosophy. Following Wittgenstein, Cavell recognizes the limited and limiting nature of our human utterances, the gap between our world and how we describe it, the frailty, in general, of our "forms of life." He speaks obsessively of Wittgenstein's call to bring words back "from their metaphysical to their everyday use," as if our words have long been estranged from us, meaningless, distant; and it might be the task of a modernist philosophy to "improvise a sense for them." Regaining lost intimacy, strangely, is a key intention of Cavell's difficult prose.

In ways that are simultaneously fascinating and frustrating, Wallace Stevens' poetry may be said to reflect this awareness, to record a comparable struggle. Stevens' scepticism about the external world (or, more precisely, his scepticism about the relation between imagination and reality) lies at the heart of his poetic investigations. Time and again, Stevens observes how reality is ultimately unreachable in thought and writing, how language never fully manages to overlap with the world of the senses. His poetry demonstrates a marked tendency to seek out the difficulties of the human experience of the world, to court the attendant frustrations of the relationship between thought and language. "The Snow Man," from Stevens' first collection Harmonium (1923), is a typical example:

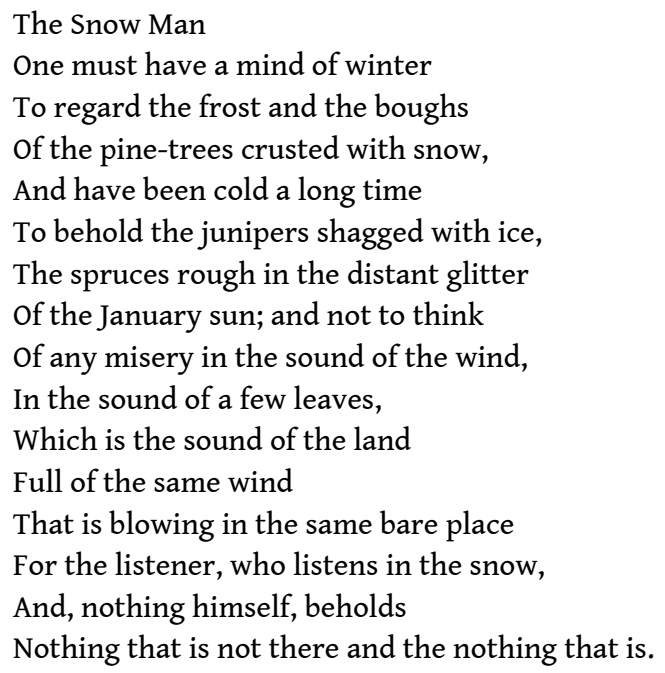

Dramatizing the possibility of a truth without human perspective, a reality devoid of imaginative correspondence, "The Snow Man" is the most frequently cited of Stevens' 
early poems of epistemology. The poem's overarching mood is one of aridity and coldness. Instead of deprivation, however, the guiding sense is of enabling freshness, of stark purity, the possibility of clearest perception. Through simple diction and concrete imagery (as a Pound or Williams might, Stevens captures the specificities of a cold, clear January), the poem lulls its reader through a single sentence, drawn out over five oddly rhymed tercets, before culminating in its infamous, seemingly paradoxical, closure. In a description that might apply just as accurately to himself, Cavell calls Stevens "this strange, wondrous, often excrutiatingly difficult writer." "The Snow Man," certainly, is both strange and difficult. Looking ahead to the disquieting reserve of "The Plain Sense of Things," the bleak detachment of "Not Ideas About The Thing But the Thing Itself" and the unsettling austerity of "The Course of a Particular," the poem introduces Stevens' essential philosophical voice as one of abstraction, impersonality, reserve.

11 This esotericism continues to Stevens' later verse, where the frameworks of human thought and language are unflinchingly studied, and found lacking. We see this in "The Poems of Our Climate" and "The Plain Sense of Things" but also, and perhaps even more starkly, in "An Ordinary Evening in New Haven." Here the poet writes, "We fling ourselves, constantly longing, on this form," highlighting not only "the difficulty of the visible" but our own engagement with this difficulty:

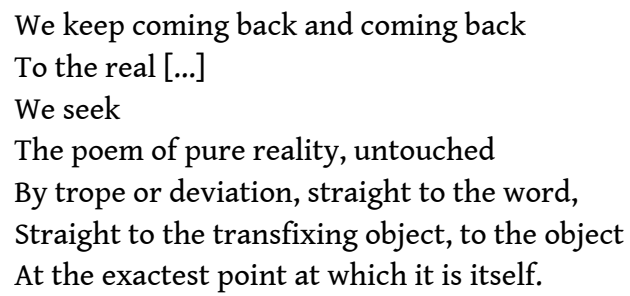

There is perhaps a tension here between Stevens' wish to investigate the limits of language and his desire to transcend language altogether, to write "the poem of pure reality, untouched / By trope or deviation." We might relate this to the desire expressed both in "The Man With The Blue Guitar" ("Throw away the lights, the definitions, [...] // But do not use the rotted names") and "Credences of Summer" ("let's see the very thing and nothing else / Let's see it with the hottest fire of sight"). The linking suggestion is that such a relation to the thing-in-itself (Kant's noumenal realm, though Stevens' is more likely to use the term "reality") is simply impossible, that reality must always be transfigured by the human imagination, and by language. As Helen Vendler has noted, Stevens' is a poetry of "enacted mental process." ${ }^{8} \mathrm{~A}$ "reflexive intelligence" (Music: 77), one that cannot evade a knowledge of its own processes, is forever fore-grounded as the subject of his poems.

Stevens and Cavell both understand that there is something both disquieting and essential about the way we possess language, that the ordinary possibilities of human communication and encounter are disappointing. As Cavell acknowledges the frailty of our agreements and encourages a greater investigation of our language use, Stevens observes, time and again, how reality is ultimately unreachable in thought and writing, how language never fully manages to overlap with the world of the senses. Its "flawed words" and "stubborn sounds" will always create a barrier between subject and object; in the central terms of his work, reality will always "resist" the imagination. For both philosopher and poet, the job is to maintain the world, to maintain language, against the corroding onslaught of scepticism. 

epistemological concern, would gladly picture language as unproblematic, or instrumental. Rorty's hunch that pragmatism is best elaborated using a Darwinian vocabulary leads to his conception of words as "tools," naturally evolved for coping with the world rather than representing it. Although he recognises the contingency of language (together with the contingency of self and community) this contingency induces in Rorty no sceptical anxiety. Rather, he seeks to alter our whole philosophical approach to language so that we are less inclined to worry about the association between it and any extra-linguistic considerations, less inclined to use language as a quasi-technical means of "bootstrapping" ourselves out of all our philosophical troubles. Rorty would prefer us to enlarge our linguistic frame of reference, to reflect on the historical fate of whole vocabularies. argued that the quest for knowledge and epistemological certitude had always been captive to its own engrossing metaphors (chief among these, famously, is that of the mind as mirror, the "glassy essence" of the soul, wherein all the representations of external reality are to be found). It thus became the task of philosophy to legitimate this picture of its work by forgetting the swerve into metaphor which first produced, and still sustains, its discourse. It became the task of philosophy, in other words, to ignore the salient fact of its textual (or rhetorical) constitution. For pragmatists and poststructuralists alike, Rorty contends, philosophy amounts to nothing more (or nothing less) than a style of writing, a literary genre and language practice. On this model, there is simply no discipline or method capable of transcending its own discourse, no way of getting beneath language to the thought it expresses, nothing to free us from the contingency of our vocabularies.

16 Like Derrida, Rorty thus rejects the protocols of orthodox linguistic philosophy in favour of a conscious, even artful, play with stylistic possibilities. At the same time, he implies that it is not just a matter of choosing one's tradition, siding (say) with Nietzsche and Heidegger as against the normative regime of stylistic oppression. Rather, it is a question of seeing that both these options come down to a choice of philosophical style, a commitment to certain operative metaphors and modes of representation. Rorty speaks in an informal, "down home," American idiom, a self-consciously pragmatist cultivation that is intended to undercut more portentous vocabularies and return human purposes to the centre of the stage. Rorty's writing has always been accented by a pacy colloquialism, a style of address that is most pronounced in the third and fourth volumes of his Philosophical Papers (1997 and 2007, respectively) and in Philosophy and Social Hope (1998), what Rorty terms "a collection of more occasional pieces." "These books are replete with Americanisms: "it didn't pan out," "put a different spin on it," "gee-whizz," "gypped," "jump-started," "pretty much," "handy ways," "pin down," "lay my cards on the table," "earn their keep," "boondoggle," "gotten some,"10 to mention but a few.

Rorty's reliance on the colloquial and idiomatic highlights the importance of American vernacular in his writing, a rhetoric he sees as singularly appropriate for the pragmatist intellectual. He writes with self-effacing charm, a quick and biting wit and a dizzying capacity for broad analogies. As his thought has changed (from analytic to non-analytic), so has his style moved increasingly from an argumentative to a narrative and "redescriptive" mode. Re-description amounts to a general recognition of the contingency of

European Journal of Pragmatism and American Philosophy, II-2 | 2010 
language, a recognition that there is no way to step outside the various vocabularies we have employed and find a "meta-vocabulary" which takes account of all possible vocabularies, all possible ways of judging and feeling. All we can ever claim is that "it would be better to say." A historicist and nominalist culture of the sort Rorty envisages would settle for this claim, for narratives which connect the present with the past, on the one hand, and with utopian futures, on the other.

The refreshing simplicity of Rorty's prose is punctuated by moments of humour and irreverence. Deflating the time-honoured distinctions within professional philosophy, for example, he writes: "So if one's teachers at Michigan assure one that Derrida is a charlatan, or if one's teachers at Tübingen suggest that formal semantics is just a mystification and cognitive science just a boondoggle, one may well believe these propositions for the rest of one's life." ${ }^{11}$ The buoyancy of this prose, together with its tongue-in-cheek depiction of academic orthodoxies, suggests a loosening of professional ties. Its seeming lack of deference indicates a philosopher both sure of his own professional contribution and his life-long regard for the discipline. This stylistic license is typical, also, of a philosopher nearing the end of his career, but it is anticipated at several brilliant moments in Rorty's oeuvre. Consider, for example, the opening paragraph of his essay "Derrida and the Philosophical Tradition" which concludes Truth and Progress: Philosophical Papers, Volume 3: "In the actual world Nietzsche was a twitchy, irresolute, nomadic nerd who never got a life outside literature. But consider the possible world in which Nietzsche got lucky early on, and wound up a happy, affectionate, suburban paterfamilias" (PP3: 327). In this alternative world, Rorty continues, The Birth of Tragedy enjoyed a European vogue and Nietzsche's U.S. lecture tours eclipsed those of Dickens, inspiring fan mail from Mark Twain and H. L. Mencken. Instead of breaking down at forty five, Rorty irreverently speculates, Nietzsche kept right on writing, joyously and prolifically, "having a great time" (PP3: 327). This paragraph culminates with the light-hearted suggestion that "success, sanity and suburbia" might have ruined Friedrich Nietzsche. Later in that same essay, Rorty muses on the equally whimsical possibility that Hegel identified the synthesis of Being and Nothingness, not as Becoming, but as "Time or Ambivalence or Sex or Fudge Ripple" (PP3: 339).

Rorty has always written with rhetorical flair and colourful elegance, prompting Harold Bloom to describe him as "the most interesting philosopher in the world" 12 and Ian Hacking to review his most recent book as "so blissfully right or infuriatingly wrong." ${ }^{13}$ Few philosophers are as engaging to read as Rorty, and few can boast his happy knack for presenting radical views (among them, his outright rejection of truth and objectivity) as an easy and agreeable shift of one's current perspective. A voice that is urbane, witty, lively and eloquent, and characteristically inflected by American cadence and idiom, Rorty's prose style is one of his supreme philosophical achievements.

Exploring the philosophical affinities between Stevens, Cavell and Rorty, what emerges most clearly is a common idea of disciplinary critique. Questioning the essence of philosophy (its status as a written discourse, its relationship to poetry and other aesthetic practices, its modernist condition, its political and social role), the trio are united, most noticeably, by a shared resistance to philosophical convention, by a willingness to challenge its time-honoured subjects and styles. We might say that each figure is 
encouraged by the "metaphilosophical," though Cavell would undoubtedly dispute such a term. ${ }^{14}$ That each figure recognises the inability of language to record or reflect the world is evident. All three would trouble the ideal of philosophical writing as transparent, as they would complicate the traditional boundaries between philosophy and poetry, poetry and prose. There is a profound sense, in the writings of all three, of the contingency of words, of the bankruptcy of language, of the deepening need to re-work existing phrases, metaphors and vocabularies.

Returning, then, to our opening epigraph, might we recognize in our philosophical trio the penury and precariousness, the desperate insecurity, that Donoghue characterises as peculiarly American? Certainly, the pursuit of one's "best and most difficult self" anticipates Cavell's modernist moment as it bespeaks his perfectionist ambition. His Emersonian desire to win through to an authentic mode of philosophical expression recognises this mode as never secure and never static, a continual striving towards one's unattained yet attainable self. Cavell, as the title of his book proclaims, is "in quest of the ordinary." We might suggest that the desperate conditions of Donoghue's stylist, "the immense strain required to make the work declare itself" (Style: 125), find their philosophical expression in Cavell's perfectionist writings, in their characteristic mood (of intensity) and momentum (of quest).

Stevens' idea of the poem as enacted mental process registers his own experience of "precariousness," his sense that the mind (or imagination) is not a mirror of nature, his profound disappointment with language, and even profounder desire to test the boundaries of human expression. In the poet's exertion of his imagination "upon situations amounting to failure" (Style: 120), Donoghue finds an affinity between Stevens and Henry James. Stevens' method, he argues, "is extensive rather than intensive" and his favoured form of theme and variation works by redeeming the blank singularity of objects. "It is a relief for Stevens," Donoghue writes, "to have thirteen ways of looking at a blackbird" (Style: 140).

Taking up Donoghue's idea, we might return to the earlier contention that Stevens' scepticism about the external world (or, more precisely, his scepticism about the relation between imagination and reality) extends to and is involved with a scepticism about language. The key point here is that Stevens' disappointment essentially proves productive; his poetry emerges most habitually from the dual resources of desire and limitation. Stevens is never settled in his poetic expression, never exactly secure. In its constant striving towards this security and stillness, however, his verse quite possibly achieves its peculiar momentum and edge, a voice that is unflinchingly "Stevens." Like Cavell, Stevens certainly exhibits touches of this characteristic, this characteristically American, "style of failure." The awareness of language's finitude leads to a struggle with language, a war with words. In both writers, and again attempting a gloss on Donoghue, conditions of desperation and struggle prove generative.

The compromises, exertions and self-defeats that Cavell and Stevens take care to register align them with a strain of American writing that wrests creativity from struggle, and style from failure. What brings poet and philosopher closest together is a shared sense of precarious involvement, a willingness to test the very boundaries of human experience and expression. These "signs of risk and strain" (Style: 125), however, are simply not to be found in the writings of Rorty. It is a mark of Rorty's neo-pragmatism that he chooses the shadow side (or maybe the happy side) of Stevens' and Cavell's acknowledgement. His own recognition of contingency leads to a celebration of language as liberating and 
creative, and to a companion emphasis on self-creation and play. Rorty is sprightly before he is anxious. Indeed, given the charges of flippancy and carelessness often levelled against him, Rorty is possibly too secure in the possession of his style. The cheerful ease of Rorty's prose reveals that he is simply untroubled by those meanings that might emerge as accidental or unintended.

Given this profound disparity, it seems misguided to extract from the present consideration of philosophical styles (offering Stevens, Cavell and Rorty, in a certain sense, as "case studies" or "examples") any levelling claims about philosophical writing in general. Stevens' status as a poet, of course, would itself postpone any such attempts at overview or generalization. The resonance of Donoghue's depiction of American literary style (with Cavell and Stevens, at least, though it is certainly more difficult to hear in Rorty), not to mention the figures' own desire to situate themselves within a native tradition, still encourages a consideration of the figures' essential Americanness, and hints, moreover, at a further avenue of inquiry: What, if anything, is to be gained by juxtaposing America's philosophical poetry with its philosophical prose? Is there a characteristically American philosophical style?

In comparing the styles of American and French philosophical writing, James Conant has recently noted the characteristic "diffidence" of writers like Thoreau when compared to the characteristic "brilliance" of intellectuals like Derrida. ${ }^{15}$ Conant provocatively suggests that this Parisian brilliance most typically registers "what is now taken as the sound of philosophy." "The sound of much of the language in Thoreau's Walden," he continues, "is apt to strike a reader - at least on a first encounter - as not particularly philosophical at all, as not even trying to sound like philosophy" (America: 60).

In comparing the sound of Emerson, James and Stevens with that of Nietzsche, Foucault and Derrida, Poirier makes a similar point: "it should be apparent by now," he writes, "that in presenting their case, the Americans simply sound different. They sound altogether less rhetorically embattled, less culturally ambitious, than do any of these European cousins. ${ }^{{ }^{16}}$ Rorty, interestingly, is quick to defend Anglo-American prose against the French. French philosophers, he urges, specialize in inventing new vocabularies. While this speciality accords nicely with his own desire to move from argument to re-description, Rorty still maintains that adopting a new vocabulary only makes sense if you can move back and forth, dialectically, between the old and the new. He writes: "It seems to us as if our French colleagues are too willing to find, or make, a linguistic islet and then invite people to move onto it, and not interested enough in building causeways between such islets and the mainland." ${ }^{17}$

The sound of Anglo-American philosophy, of course, is a central preoccupation of Cavell's. "About my own sound," he writes, "it may help to say that while I may often leave ideas in what seems a more literary state, sometimes in a more psychoanalytic state, than a philosopher might wish [...] I mean to leave everything I will say, or have, I guess, ever said, as in a sense provisional, the sense that it is to be gone on from." 18 Certainly, Cavell's style owes just as much to psychoanalysis as it does to philosophy, emphasizing the temptations and anxieties of the speaking self, employing language as a form of therapy. In conceding Wittgenstein's emphasis on the functions and contexts of language as fundamental to American pragmatism, furthermore, Cavell is more concerned to stress how different their arguments sound. "And in philosophy," he writes, "it is the sound which makes all the difference" (MMW: 36 fn31). As a student of Cavell's, Conant would be well aware of this centrality, not only in Cavell's desire to maintain his 
distance from pragmatism, but in his broader philosophical project. Aside from noting the "diffident" and "non-philosophical" sound of Thoreau, however, Conant doesn't push further on what a characteristically American philosophical writing might sound like.

Diffidence, surely, is rarely audible in Rorty. Though his style is unaffected, and his ambitious claims presented with disarming modesty, he is more likely to give the impression of self-assurance (his harshest critics would say "brashness") than timidity or reserve. Interestingly, his colleagues have always drawn attention to the curious disparity between his spoken and written tone. Rorty's voice, as Daniel Dennett notes, "is sort of striking - those firebrand views delivered in the manner of Eeyore." Of Rorty's mode of presentation, the British philosopher Jonathan Rée says, "There's a tremendous kind of melancholy about it. He tries to be a gay Nietzschean, but it's an effort for him." For Conant, hearing Rorty speak for the first time was something of a revelation. "It's easy to read his writings in a register of excitement and a heightened breathless voice," he explains. "But the note that I heard when he was reading these sentences in his own cadence and rhythm was - for want of a better word - depression. I thought, this is the voice of a man who feels as if he's been let down or betrayed by philosophy." Jürgen Habermas similarly concurs that Rorty's antiphilosophy "seems to spring from the melancholy of a disappointed metaphysician." 19

The disparity between Rorty's written and spoken voice contrasts interestingly with Cavell, whose audiences have always commented on their striking continuity. Paul Jenner has traced this correspondence to Cavell's training in music, to the philosopher's avowed desire to return the human voice to philosophy ${ }^{20}$ Jenner writes: "At odds with the prevailing philosophical fashion, with Derrida's post-structuralist and deconstructive wish to unpick the dominance of the voice (understood in opposition to a denigrated "writing") within the philosophical canon, Cavell's appeal to the voice is manifest in Austin and Wittgenstein's appeal to the ordinary or everyday in language. The appeal to the voice, in this sense, need not be understood as an instance of Derrida's metaphysics of presence; it is more suggestive of fracture and failure, of a habitual distance in our relations to self, others, world and language." ${ }^{21}$

Conant's suggestion of American writing as diffident is further troubled, of course, by the curiously non-Thoreauvian pitch of Cavell. Cavell has always sought, as Jenner and others point out, to distance himself from the institutional dominance of deconstruction, taking care to present himself as an American writer inheriting a specifically American tradition. His misgivings toward deconstruction, however, are to be sharply distinguished from his evaluation of Derrida as a philosopher. There is, for Cavell, notable affinities between his own writing and that of Derrida; most importantly, the philosophers share a sense of the necessity in questioning the grounds of their own philosophy and discourse. ${ }^{22}$ In many ways, Cavell comes closer to Derrida than Rorty, even though it is Rorty who has consistently championed Derrida as the ultimate writer of philosophy, the ultimate strong poet, the ultimate "maker of the new." This leads to a paradoxical situation, and again frustrates any easy generalizations about native philosophical style. Rorty sounds like an American, certainly, but more the gaudy American of cultural stereotype than the diffident figure at Walden. Meanwhile, the quiet gentilities of Cavell's prose can surely remember Thoreau, but their spiralling self-consciousness can just as easily recall the indirections (less sympathetic critics would say the "indulgences") of Derrida. book charted "a poetico-philosophical no-man's land" and, by doing so, that it occupied 
"the buffer zone between poetry and philosophy in a unique and perhaps uniquely American way." ${ }^{23}$ In responding to Hollander's review, Cavell wrote: "It is greatly heartening to me that Hollander finds a weight for 'poetic' with which my philosophizing may be found poetic. I believe Hollander is right in finding my mode essentially American." ${ }^{24}$ That Hollander, himself a highly regarded philosopher and poet, considers Cavell's "poetico-philosophical" expression distinctively American is suggestive. Cavell's gracious response is anticipated by his own desire to hear the romanticist redemption of philosophy by poetry in his own writing, together with his desire to view America in general as the place that promises romanticism, that promises to heal the wound between philosophy and literature that has been festering since Plato's Republic. ${ }^{25}$

Equally suggestive, and certainly more surprising, is the companion attention to this poetico-philosophical "no-man's land" or "buffer zone" encouraged, albeit indirectly, by the pragmatist philosopher, Cornel West. In The American Evasion of Philosophy, in seeking to consolidate Emerson's status as America's proto-pragmatist, West quotes Dewey, who in turn quotes Emerson: "[Emerson] would work, he says, by art, not metaphysics, finding truth "in the sonnet and the play." 'I am,' to quote him again, 'in all my theories, ethics and politics, a poet,' and we may, I think, safely take his word for it that he meant to be a maker rather than a reflector. His own preference was to be ranked with the seers rather than with the reasoners of the race." ${ }^{26}$ Dewey understands Emerson's evasion of philosophy, West argues, as neither a simple replacement of philosophy by poetry nor a rekindling of the Platonic quarrel. Instead, this evasion is to be understood as "a situating of philosophical reflection and poetic creation in the midst of quotidian struggles for meaning" (Evasion: 73). This Emersonian evasion, which West proposes to extend to all of American philosophy, views poetry and philosophy neither as identical nor as antagonistic, but "as different metaphor-deploying activities to achieve specific aims" (Evasion: 73).

In West's formulation, American pragmatism can be understood as what happens to the Emersonian evasion of epistemology-centred philosophy when forced to justify itself within the professional perimeters of academic philosophy. Whereas Peirce applies the Emersonian themes of contingency and revisability to the scientific method, West argues, James extends them to our personal and moral lives. The emphasis on poetry and art, "on the seers rather than the reasoners of the race," that he extracts from Dewey's reading of Emerson is duly translated into West's own pragmatist programme, into his emphasis on the centrality of "metaphor-deploying activities." This latter phrase would certainly resonate with Rorty. Priding themselves on evading philosophy, both Rorty and West would extend the meaning of "metaphor-deploying activities," from "poetic creation" to "cultural criticism," and so define the ambitions of pragmatism in general.

Cavell, of course, has long registered both his discomfort with pragmatism, and the related efforts, of West and Rorty among others, to establish pragmatism as the essentially American philosophical voice. The proposed assimilation of Emerson to pragmatism, according to Cavell, "unfailingly blunts the particularity, the achievement, of Emerson's language." ${ }^{27}$ The Emerson with whom he seeks to affiliate his own work differs significantly from the proto-pragmatist posited by West as the chief source of this line of American thought. Cavell wants to demonstrate an Emerson to whom others have condescended or who they have simply ruled out: an Emerson well aware of the power of evil, the potential of tragedy, and the full weight of scepticism; an Emerson as receptive as he is assertive, and much closer to Wallace Stevens than he is to Dewey or to Quine. 
existentialist Emerson, surely, could just as easily be aligned with the strain of American literature identified by Donoghue. His own "desperate scepticism" might be registered by the indirections and meanderings of his prose, the formal feature that brings Emerson closest to Cavell. Both Emerson and Cavell demonstrate a willingness to follow through on idea or example unsure of the final destination or upshot, letting ideas "find their weight" in their individual emergences. Captured in their emphasis on the sound of the prevailing philosophical vocabulary, furthermore, is the alternative sense of sound as measurement. Cavell, for one, would certainly welcome a comparison between his and Emerson's "sounding" of the depths of language and Thoreau's activities at Walden. Sounding and weighing are activities that require patience, and Cavell follows the transcendentalists in continually counselling persistence, waiting, resourcefulness and hope, "in the face of discouraging odds and the inevitability of disappointment." 28 Wishing to stay faithful to their own volatility and instinct, Emerson and Cavell proceed always by indirection and improvisation, following Donoghue's traditional American stylist "who does not rush upon it - he delays, allowing the forms to do their best work" (Style: 103). ${ }^{29}$

Returning to The American Evasion of Philosophy, we might identify certain aesthetic strands that emerge from West's account that exceed the scope and intention of his own book. These strands, in turn, might yet conciliate those philosophers who find in American philosophy alternative resonances to pragmatism. West writes of "poetic creation" as a "metaphor-deploying activity," one that exemplifies the heights of human intelligence at work, "the best of conscious and reflective human activity" (Evasion: 73). Poetic creation, in this sense, is taken from poetry's etymological root, "poeisis," meaning the creative production of meaning. It is undoubtedly this sense of poetry that allows Rorty to align such diverse figures as Galileo and Yeats, Francis Bacon and John Milton. ${ }^{30}$ Choosing the more traditional sense of "poetic creation," however, we are lead to more formal implications, to an idea of writing that privileges not just the contingent and the revisable, but the figural and the logically evasive: more poetry than poeisis, to put it simply.

peculating further, we might weave these aesthetic strands into an alternative narrative of American philosophy. On this re-description, "evasion" might not signal a traditionally American avoidance of problems of knowledge or criteria of certainty. Donoghue and Poirier, certainly, find these problems consistently taken up by American literature, as they go to the very heart of the philosophical life of Emerson, of Stevens, and of Cavell. "Evasion," rather, if understood in its literary critical sense of "ambiguity" or "vagueness," might gesture towards the kind of writing that even neo-pragmatism is keen to encourage, if not always to enact. In Rorty's own terms, this form of philosophical expression is suggestive and multialent, "funnier, more allusive, sexier and, above all, more 'written'." 31

41 Finding in West's narrative this alternative story of American philosophy, we are reminded of the "poetico-philosophical no-man's land" that Hollander once pictured as uniquely American. Such a region, Hollander wrote, might offer a distinctively American way of mediating between analytic and continental traditions. ${ }^{32}$ With these American evasions and mediations in mind, an alternative sense and significance for "poetic creation" in the story of American philosophy emerges. On this model, philosophical expression is prized for aesthetic and evocative qualities as well as transparency. Alternative conceptions of lucidity and completeness, alternative ways of being precise, 
are entertained. Emerson's central status, in turn, might be founded less on his metaphor-deploying activity, and more on the curious indirections of his prose. He might emerge as the philosophical predecessor not only of Dewey, Quine and Rorty, but of Santayana, Stevens and Cavell. These latter figures undoubtedly inhabit the poeticohilosophical "no-man's land" and return us, finally, to the possibility of a distinctively American philosophical style: a style that opens to the evasive, the excessive and the 'written,' that answers to America's poets as well as her pragmatists.

\section{NOTES}

1. D. Donoghue (1976), "The American Style of Failure," in The Sovereign Ghost: Studies in Imagination, California, University of California Press, 126; hereafter abbreviated Style.

2. Tony Tanner makes a similar point, noting the American writer's "dread of all conditioning forces" and his "general self-consciousness about the strange relationship between words and things." T. Tanner (1971), City of Words American Fiction, 1950-1970, London, Cape, 16.

3. S. Cavell (1989), In Quest of the Ordinary: Lines of Skepticism and Romanticism, Chicago, University of Chicago Press, 73; hereafter abbreviated IQO.

4. S. Cavell (2005), Cities of Words: Pedagogical Letters on a Register of the Moral Life, New York, Harvard University Press, 8.

5. S. Cavell (1976), Must We Mean What We Say?: A Book of Essays, Cambridge, Cambridge University Press, 213-27; hereafter abbreviated MWM.

6. Paul Jenner (2002), "The Philosophy of Stanley Cavell: Its Context and Early Development" (Unpublished doctoral thesis, University of Nottingham), 34.

7. S. Cavell (2006), "Reflections on Wallace Stevens," in C. Benfey and K. Remmler, (eds.), Artists, Intellectuals and World War II: The Pontigny Encounters at Mount Holyoke College, 1942-1944, Amherst, University of Massachusetts Press, 61.

8. H. Vendler (1988), The Music of What Happens: Poems, Poets, Critics, Cambridge, Mass., Harvard University Press, 77; hereafter abbreviated Music.

9. R. Rorty (2009), Philosophy And Social Hope, London, Penguin Books, v.

10. This phrase is used in Rorty's playful "re-imagining" of Nietzsche's biography. He writes: "Could [Nietzsche] have written so well against resentment if he had experienced it less often? Could he have written The Will to Power if he had gotten some? Maybe not." Rorty (1998), Truth and Progress, in Philosophical Papers, Volume 3, Cambridge, Cambridge University Press, 327; hereafter abbreviated PP3.

11. R. Rorty (2007), Philosophy as Cultural Politics: Philosophical Papers Volume 4, Cambridge, Cambridge University Press, 121.

12. H. Bloom (1989), book jacket of Contingency, Irony, and Solidarity, Cambridge, Cambridge University Press.

13. I. Hacking, book jacket of Philosophy as Cultural Politics: Philosophical Papers, Volume 4, op. cit..

14. In the foreword to Must We Mean What We Say?, Cavell writes: "If I deny a distinction, it is the still fashionable distinction between philosophy and meta-philosophy, the philosophy of philosophy. The remarks I make about philosophy (for example, about certain of its differences from other subjects) are, where accurate and useful, nothing more or less than philosophical remarks, on a par with remarks I make about acknowledgement or about mistakes or about 
metaphor. I would regard this fact - that philosophy is one of its own normal topics - as in turn defining for the subject, for what I wish philosophy to do" (MWM: xviii).

15. J. Conant (2005), Cavell and the Concept of America, in R. Goodman (ed.), Contending with Stanley Cavell, Oxford, Oxford University Press, 60; hereafter abbreviated America.

16. R. Poirier (1992), Poetry and Pragmatism, Cambridge, Mass., Harvard University Press, 155; hereafter abbreviated Poetry.

17. R. Rorty (1991), Objectivity, Relativism, and Truth: Philosophical Papers Volume 1, Cambridge, Cambridge University Press, 221.

18. S. Cavell (1990), Conditions Handsome and Unhandsome: The Constitution of Emersonian Perfectionism, Chicago, University of Chicago Press, 33.

19. R. Rorty \& E. Mendieta (2006), Take Care of Freedom and Truth Will Take Care of Itself: Interviews with Richard Rorty, Stanford, Stanford University Press, 15-6.

20. Paul Jenner, "The Philosophy of Stanley Cavell: Its Context and Early Development" (unpublished doctoral thesis, University of Nottingham, 2002).

21. Ibid.: 98.

22. Ibid.: 115.

23. J. Hollander (1980), "Stanley Cavell and The Claim of Reason," Critical Inquiry, Summer, 575-8.

24. S. Cavell (1980), “A Reply to John Hollander," Critical Inquiry, Summer, 589-91.

25. As Cavell writes in "The Philosopher in American Life," "In the New World, philosophy and literature do not exist in separation" (IQO: 82).

26. C. West (1989), The American Evasion of Philosophy: A Genealogy of Pragmatism, Madison, University of Wis- consin Press, 73; hereafter abbreviated Evasion.

27. S. Cavell (2003), Emerson's Transcendental Etudes, Stanford, Stanford University Press, 7.

28. Paul Jenner (2002), “The Philosophy of Stanley Cavell: Its Context and Early Development" (Unpublished doctoral thesis, University of Nottingham,), 89.

29. This tendency towards improvisation, interestingly, is central to the tradition of American reading and writing highlighted by Poirier in Poetry and Pragmatism, op. cit. "Emerson is not writing theatrically," Poirier argues, "not dramatizing an argument already made in his head. Instead, he is exploring his language as it emerges, disco- vering the dense and terrifying implications of his way of thinking and of his way with words" (Poetry: 57).

30. These are the central figures that Rorty will label, in Contingency, Irony and Solidarity, as "strong poets," thinkers that successfully redescribe outworn vocabularies.

31. R. Rorty (1982), Consequences of Pragmatism: Essays, 1972-80, Minneapolis, University of Minnesota Press, 93.

32. This mediation, interestingly, is a central concern of both Cavell and Rorty. Perhaps it is announced most explicitly by their common willingness to find moments of intersection in the work of Heidegger and Wittgenstein.

\section{ABSTRACTS}

Writing on the death of Jean Baudrillard in March 2007, Julian Baggini dismissed Anglo-American philosophy (as compared to its French counterpart) as utterly without style, as "the literary equivalent of Alan Partridge's sports-casual fashion collection." A damning indictment, indeed. Contesting Baggini's claim, this article proposes an American poet and two American 
philosophers - Wallace Stevens, Stanley Cavell and Richard Rorty - as supreme stylists of the philosophical. Combining elegance and verve with an edifying mix of philosophical dedication and critique, the chosen trio are philosophical stylists in the best sense of the term. With due attendance to their inheritance of the transcendentalist and pragmatist legacies, I propose an engagement with their writing styles as opening instructively to a broader consideration of philosophical writing in America, including the possibility of a distinctively American philosophical style. 